М. Монтень, наука не може осяяти душу світлом, яка позбавлена його. «Тому, хто не осягнув науки добра, будь-яка інша наука приносить тільки шкоду» [8, с. 154].

I. Кант проголошує людину як найвищу цінність і ціль у вихованні. Доброчесність, на думку філософа, є згода волі людини з ії обов'язком. Виконання цілей людиною $є$ обов'язком, а прагнення та виконання максими цілей є доброчесність. Вищий принцип учення філософа про доброчесність полягає у тому, що: «Чини згідно з такою максимою цілей, мати яку може бути для кожного загальним законом. Згідно з цим принципом, людина становить ціль як для самої себе, так і для інших, ... зробити людину взагалі своєю метою є сам по собі ії обов'язок» [4, с. 329].

I. Кант розмірковує над проблемою набуття людиною доброчесності. На його думку, доброчесності можна й слід навчати, вона $є$ продуктом чистого практичного розуму, який грунтується на свободі людини та бере верх над ії̈ дурними нахилами. Правилами вправляння в доброчесності $є$ два види стану духу - бадьорий і веселий настрій. Мислитель, проголошуючи важливість культури доброчесності, висловлює життєве гасло для людини: «Привчай себе переносити життєві негаразди й обходитись без зайвих насолод» [4, с. 429].

Отже, здійснений аналіз думок філософів минулого довів, що їхні ідеї донині $\epsilon$ актуальними. В усі часи людство буде жити, розвиватися і процвітати тільки за умов духовноморального виховання. Оскільки професійна діяльність набула вагомого значення в житті будьякої людини, то важливого значення набуває й формування духовно-моральних основ ії професійної поведінки. 3 урахуванням сучасних умов розвитку суспільства доцільним $\epsilon$, використання філософських думок у процесі підготовки майбутнього фахівця, здатного розмірковувати й діяти згідно з совістю і професійною честю.

\title{
Література
}

1. Аристотель. Сочинения: в 4-х т. - Т. 4 / пер. с древнегр.; общ. ред. А. И. Доватура. - М. : Мысль, 1983. - 830 с. 2. Грановская Р. М. Психология веры / Р. М. Грановская. - [2-е изд., перераб.] - СПб. : Питер, 2010. - 480 с. 3. Етика: [навч. посіб.] / В. О. Лозовой, М. І. Панов, О. А. Стасевська та ін.; за ред. проф. В. О. Лозового. - К. : Юрінком Інтер, 2002. - 224 с. 4. Кант И. Сочинения / под ред. В. Ф. Асмуса; в 6 т. - Т. 4, Ч. 2. - М. : Мысль, 1965. - 544 с. 5. Лаэртский Д. О. О жизни, учениях и изречениях знаменитых философов / пер. и прим. М. Л. Гаспарова; общ. ред. и вступ. ст. А. Ф. Лосева. - М. : Мысль, 1979. - 624 с. - (Серия «Философское наследие»). 6. Леонардо Да Винчи. Сказки, легенды, притчи / [пер. и предисл. А. Махов]. - М. : Издательство А. П. Выродова, 2002. - 168 с. 7. Материалисты Древней Греции / Собрание текстов Гераклита, Демокрита, Эпикура / под ред. М. А. Дынника. - М. : Госполитиздат (Акад. наук СССР ин-ут Философии), 1955. - 238 с. 9. Монтень М. Опыты. Избранные произведения / [пер. с фр.]; в 3-х т. - Т. 1. - М. : Голос, 1992. 384 с. 10. Переломов Л. С. Конфуций : Лунь Юй / Л. С. Переломов. - М. : «Восточная література», 2001. - 168 с. 11. Платон. Сочинения / под общ. ред. А. Ф. Лосева, В. Ф. Асмуса; [пер. с древнегр.]; в 3-х т. - Т. 3, Ч. 2. - М. : Мысль, 1972. - 678 с. 12. Сагадеев А. В. Ибн-Сина (Авиценна) / А. В. Сагадеев. - М. : Мысль, 1980. - 239 с. 13. Фрейд 3. Леонардо да Винчи. Воспоминание детства. М. : Олимп; ООО «Издательство АСТ-ЛТД», 1998.

УДК 7: 316.77:316.454.52

Тетяна Шепеленко

\section{СПІВВІДНОШЕННЯ ПОНЯТЬ «КОМУНІКАЦІ», «СПІЛКУВАННЯ», «КОМУНІКАТИВНА ДІЯЛЬНІСТЬ» ЯК ПЕДАГОГІЧНА ПРОБЛЕМА}

Шепеленко Т. Л. Співвідношення понять «комунікація», «спілкування», «комунікативна діяльність» як педагогічна проблема.

У статті з'ясовано поняття «комунікативна діяльність» через розкриття його співвідношення 3 поняттями «комунікація», «спілкування». Визначено розглядуване поняття як комунікативну діяльність, яка є взаємодією двох і більше людей, спрямованою на узгодження і об'єднання їх зусиль задля налагодження стосунків і досягнення спільного результату.

Ключові слова: комунікація, спілкування, комунікативна діяльність.

Шепеленко Т. Л. Соотношение понятий «коммуникация», «общение», «коммуникативная деятельность» как педагогическая проблема.

В статье рассмотрено понятие «коммуникативная деятельность» посредством раскрытия его соотношения с понятиями «коммуникация», «общение». Определено рассматриваемое понятие как коммуникативная деятельность, которая является взаимодействием двоих и 
больше людей, направленной на координацию и обьединение их усилий с целью налаживания отношений и достижения общего результата.

Ключевые слова: коммуникация, общение, коммуникативная деятельность,

Shepelenko T. L. Value concepts of «communication», «communication», «communicative action» as a pedagogical problem.

The paper clarifies the concept «communicative activity» by opening its relationship with the concepts «communication», «conversation». The proposed concept is considered as a communicative activity that is the interaction of two or more people, aimed at harmonizing and pooling their efforts for establishing and achieving common results.

Key words: communication, conversation, communicative activity.

Досліджувана проблема комунікативної діяльності $\epsilon$ складною і багатоаспектною. Останнім часом педагогічну теорію й практику все більше цікавить проблема взаємодії суб'єктів педагогічного процесу, що потребує розгляду педагогічної діяльності як комунікативної. Це пов'язано 3 різними підходами до розгляду понять «комунікація», «спілкування», «комунікативна діяльність».

Феномен комунікативної діяльності за своїми виявами настільки різнобарвний та різноаспектний, що є предметом зацікавленості філософів (Б. Ананьєв, Г. Андреєва, Л. Буєва, М. Каган та ін.), психологів (О. Бодальов, Я. Коломинського, Н. Кузьміна, О. Леонтьєв, Б. Ломов та ін.), педагогів (І. Зязюн, В. Кан-Калик, Л. Коваль, М. Сагач, В. Сластьонін та ін.), у роботах яких розкриваються різні аспекти досліджуваної проблеми. Щодо питання співвідношення досліджуваних категорій, то воно не знайшло достатнього висвітлення в науковій теорії.

Метою статті є висвітлення сутності поняття «комунікативна діяльність» через розкриття ії̈ взаємозв'язку з поняттями «комунікація», «спілкування».

У науці існує багато визначень поняття «комунікація». Аналізуючи їх, розуміємо, що це не $є$ дефініції, які суперечать одна одній, вони лише доповнюють одна одну. Кожне з визначень охоплює певний аспект явища, що допомагає більш глибокому осягненню сутності комунікації. Слово «комунікація» в перекладі $з$ латинської позначає «спілкуюся 3 кимось, передаю інформацію». Українським відповідником поняття «комунікація», яке прийшло до нас через англійську мову, $є$ такі поняття, як спілкуватися, спільнота, спілкування.

Очевидно, що розглядати поняття «комунікативна діяльність» необхідно через призму співвідношення понять «комунікація» $\mathrm{i}$ «педагогічне спілкування».

Так, Е. Соколов дотримується думки, що комунікація - це «найважливіший аспект людського спілкування. Вона полягає в обміні значущою інформацією між людьми. Комунікація припускає цілеспрямовану передачу і вибірковий прийом інформації, хоча вона не завжди призводить до згоди і взаєморозуміння» [9, с. 102].

У цьому ж аспекті вводить поняття «комунікації» і встановлює взаємозв'язок між спілкуванням і комунікацією М. Каган, який розуміє комунікацію як інформаційний зв'язок суб'єкта $з$ тим або тим об'єктом - людиною або машиною. Суб'єкт передає інформацію, яку об'єкт повинен передовсім сприймати, розуміти, засвоювати її і відповідно до неї діяти. Об'єкт в такій ситуації виступає приймачем, добре настроєним, який точно і надійно працює. Але відправник інформації може бачити в іiі одержувачі не об'єкт, а суб'єкт, який переробляє інформацію, виходячи зі своєї індивідуальності, і через це стає партнером спільного вироблення результуючої інформації. «Значить, - говорить автор, - якщо мова йде не просто про обмін інформацією, не про підпорядкування одного іншому, а про сумісний пошук істини, загальну позицію, спілкування може розглядатися як процес вироблення нової інформації, загальної для людей, що спілкуються, і народжує їх спільність» [3, с. 149].

Тому, стверджує науковець, можна говорити про дві форми інформаційної активності: виконання (коли той, хто сприймає інформацію, є об'єктом) і взаємодію (коли той, хто сприймає інформацію, є суб'єктом). У другому випадку спілкування розглядається як комунікативна діяльність, від кожного учасника якої потрібна здатність суміщати позиції об'єкта і суб'єкта діяльності, здатність переключатися з ролі об'єкта в роль суб'єкта. Тобто, вважає М. Каган, тим, що спілкуються, необхідно розуміти, де і коли найбільш ефективні комунікація-монолог, а де і коли оптимальні спілкування-діалог, ставлення один до одного як суб'єктів. 
Плідну спробу 3'ясувати співвідношення понять «комунікація» і «спілкування», «комунікативна діяльність» зробив В. Семенов. Спілкування і комунікація, на думку автора, розрізняються за внутрішніми установками комунікатора під час його орієнтації на окремого індивіда або ж на яку-небудь соціальну групу. Автор відзначає, що такі важливі характеристики спілкування як «взаємодія» й «обмін» підкреслюють їх обопільний, активний характер. Проте, найважливіша відмінність спілкування від комунікації полягає в тому, що комунікація може бути й односторонньою. Якщо в безпосередньому контакті виявляється активний двосторонній інформаційний взаємообмін між його учасниками, то у випадку 3 комунікацією ці складники можуть мати різну якісну представленість. Виходячи 3 цього, науковець характеризує комунікацію і спілкування в межах комунікативної діяльності, що полягає, «у взаємному обміні індивідуально-особовим змістом» [9, с. 191-192].

Отже, спілкування і комунікація як складники комунікативної діяльності представляють єдине утворення, складне не тільки за формою його вияву, але й за психологічними механізмами, що забезпечують його.

Із позиції діяльнісного підходу спілкування розглядається науковцями в двох аспектах: як атрибут діяльності і як самостійний вид суб'єкт-суб'єтної діяльності - комунікативної діяльності. Так, Б. Ломов, розглядаючи взаємозв'язок спілкування і діяльності, пише, що «іноді спілкування розглядається як один з видів діяльності. Говорять про «діяльність спілкування», «комунікативну діяльність». Виникає, проте, сумнів: чи правомірно розчиняти спілкування в діяльності, розглядати його лише як окремий випадок діяльності» [7, с. 126]. Визначаючи спілкування як взаємодію людей, вважаємо, що воно $є$ вплетеним у діяльність і постає умовою ії виконання.

Л. Буєва вважає, що спілкування і діяльність - це дві взаємозв'язані, відносно самостійні, але не рівноцінні сторони певного (індивідуального або суспільного) процесу життя [4, с. 113]. Такої ж позиції дотримується й О. Леонтьєв, визначаючи спілкування як один 3 видів діяльності. При цьому автор указує, що «це не означає, що спілкування у всіх випадках $\epsilon$ самостійною діяльністю; важливо, що воно може бути таким, хоча і може бути компонентом інших не комунікативних видів діяльності» [5, с. 12].

О. Леонтьєв зазначає, що спілкуванню як діяльності притаманна така структура: специфічна мета, специфічна мотивація, нормативність, яка виявляється у факті соціального контролю за перебігом і результатами акту спілкування, результативність, тобто міра збігу отриманого результату з метою [6]. Відповідно до цієї структури, Б. Ананьєв виокремлює такі структурні компоненти спілкування як виду діяльності: предмет спілкування - інша людина, партнер по спілкування як суб'єкт; потреба у спілкуванні - прагнення людини до пізнання й оцінки інших людей, а через це та 3 допомогою цих інших - до самопізнання й самооцінки; комунікативні мотиви - те, що спонукає людину до спілкування (відповідно до названого предмета спілкування, і втілюються або «опредмечуються», у тих якостях цієї людини або інших людей, ради пізнання та оцінки яких вона вступає у взаємодію з оточуючими); дії спілкування - одиниці комунікативної діяльності, цілісні акти, адресовані іншій людині та спрямовані на неї як на свій об'єкт; завдання спілкування - те, на досягнення чого в конкретних умовах спрямовані різноманітні дії, що здійснюються у процесі спілкування; засоби спілкування - ті операції, через які реалізуються дії спілкування; продукти спілкування матеріальні та духовні утворення, що виникають у процесі спілкування [1].

Спробу синтезувати різні підходи зробила Г. Андреєва, яка розглядає спілкування і як спільну діяльність, і як продукт цієї діяльності, стверджуючи, що «не тільки праця, але й спілкування в процесі праці є діяльністю» [2, с. 95].

Зауважимо, що за наявності розбіжностей у поглядах, причина яких криється в тому, що діяльність - це активність, спрямована на перетворення об'єкта, а спілкування - це взаємодія, де об'єкт - завжди суб'єкт, інакше немає взаємодії, методологічна спільність цих підходів виявляється в тому, що в них поділяється точка зору на єдність спілкування і діяльності, яка виявляється в наявності спільної якості - бути відносно самостійними формами соціальної активності індивідів.

Дійсно, немає діяльності поза спілкуванням. У свою чергу спілкування володіє всіма характеристиками діяльності, тільки діяльності, що відтворює саму людину, тобто, коли сама людина $є$ предметом діяльності. Співвідношення спілкування і діяльності, необхідно розглядати як взаємодію, яка виникає і здійснюється в результаті діалектичної єдності 
одночасного перебігу комунікативних діяльностей двох або більше індивідів як суб'єктів і об'єктів спілкування. Спілкування немає без комунікативної діяльності партнерів по спілкуванню, але воно і не зводиться до їх ізольовано взятих діяльностей. Визнаючи за комунікативною діяльністю право на самостійне існування, автор стверджує, що вона, як будьяка інша, має мотиви, мету. Об'єктом комунікативної діяльності одного із учасників спілкування $\epsilon$ інша людина, а предметом - іiї внутрішній світ. Як будь-яка інша, комунікативна діяльність складається із низки комунікативних дій.

А. Петровський, підкреслюючи значення взаємодії і взаємної зумовленості спілкування й діяльності, розглядає діяльність як сферу предметної взаємодії, а спілкування як сферу позапредметної суб'єкт-суб'єктної взаємодії рівноцінних сторін [8]. Отже, автор визнає існування спілкування як самостійного виду діяльності. У цьому зв'язку Я. Коломинський зазначає, що «спілкування - це особливий вид діяльності, об'єктом якого є інша людина, предметом - іiі внутрішній світ (почуття, прагнення, погляди, переконання, знання і тощо, метою є зміни в цій картині світу, відповідні усвідомлюваним або неусвідомлюваним потребам суб'єкта, а засобами - вся сукупність інформаційних дій - мови, міміки, жестів. При цьому партнери є одночасно один для одного і об'єктами, і суб'єктами діяльності» [4, с. 46].

Спілкування слід розглядати як визначену сторону діяльності, тому що воно присутнє в будь-якій діяльності як ії елемент. Саму ж діяльність можна розглядати як необхідну умову спілкування. Але зв'язок спілкування й діяльності полягає саме в тому, що завдяки спілкуванню діяльність організується. Специфіка спілкування в процесі діяльності полягає у створенні можливості організації та координації діяльності, іiі окремих учасників. У спілкуванні відбувається збагачення діяльності, розвиваються й утворюються нові зв'язки та стосунки між людьми. Поєднання діяльності однієї людини з діяльністю інших людей утворює спільну діяльність.

Отже, можна стверджувати, що у спільній діяльності формуються не тільки суб'єктоб'єктні (людина - предмет діяльності), а й суб'єкт - суб'єктні відносини (людина - людина). Сутність спілкування полягає у взаємодії суб'єктів діяльності, тому воно є одним із видів діяльності і у всіх випадках виступає як самостійна діяльність.

Узявши за основу аналіз концепцій відомих педагогів та психологів, які вважають що спілкування в педагогічній діяльності є самостійним видом професійної діяльності, вважаємо можливим визначити це поняття як комунікативну діяльність, яка є взаємодією двох і більше людей, спрямованою на узгодження і об'єднання їх зусиль задля налагодження стосунків i досягнення спільного результату.

Отже, здійснений аналіз літературних джерел свідчить, що проблема співвідношення комунікації, спілкування і діяльності отримала широке визнання і розроблення в працях філософів, психологів і педагогів. Проте, той факт, що донины ще не вдалося однозначно виробити загальноприйняте положення, вказує на складність і значні труднощі в дослідженні окресленого феномену.

\section{Література}

1. Ананьев Б. Г. О соответствии способностей и одаренности / Б. Г. Ананьев // Проблемы способностей. - М. : Изд-во АПН РСФСР, 1994. - С. 15-31. 2. Андреева Г. М. Социальная психология: [учеб. для высш. школы] / Г. М. Андреева. - М. : Аспект Пресс, 1996. - 376 с. 3. Каган М. С. Мир общения: Проблемы межсубъективных отношений / М. С. Каган. - М. : Политиздат., 1988. - 319 с. 4. Коломинский Я. Л. Психология общения / Я. Л. Коломинский. - М.: Знание, 1974. 96 с. 5. Леонтьев А. А. Общение как объект психологического исследования. Методологические проблемы социальной психологии / А. А. Леонтьев. - М. : Наука, 1975. - С. 106-123. 6. Леонтьев А. Н. Некоторые психологические вопросы воздействия на личность / А. Н. Леонтьев // Проблемы научного коммунизма. - М., 1968. - Вып. 2. - С. 30-42. 7. Ломов Б. Ф. Общение как проблема общей психологии / Б. Ф. Ломов // Методологические проблемы социальной психологии; под ред. Е. В. Шороховой. - М. : Наука, 1975. - С. 124-135. 8. Петровский А. В. Личность. Деятельность. Коллектив / А. В. Петровский. - М. : Политиздат., 1982. - 255 с. 9. Соколов Е .В. Смысл и культура человеческого общения / Е. В. Соколов // Духовное становление человека: сб. ст. М. : Знание, 1972. - С. 100-124. 